\title{
KEJADIAN KATARAK PADA KELOMPOK NELAYAN “PUTRA SAMUDRA” DI DESA LEBIH, GIANYAR, BALI TAHUN 2016
}

\author{
Ni Kadek Nening Andiyani, Partha Muliawan* \\ Program Studi Kesehatan Masyarakat Fakultas Kedokteran Universitas Udayana \\ *Email: partha.muliawan@gmail.com
}

\begin{abstract}
ABSTRAK
Penyebab kebutaan terbanyak di seluruh dunia disebabkan oleh katarak. Prevalensi katarak berdasarkan status pekerjaan didapatkan pekerjaan petani, nelayan, buruh merupakan pekerjaan yang paling banyak mengalami katarak. Tujuan dari penelitian ini adalah untuk mengetahui gambaran kejadian katarak pada kelompok nelayan "Putra Samudra" di Desa Lebih. Penelitian ini menggunakan desain cross-sectional study dengan pendekatan deskriptif kuantitatif. Sampel penelitian sebanyak 70 orang yang merupakan bagian dari 187 anggota dari nelayan "Putra Samudra". Teknik pengambilan sampel yang digunakan adalah simple random sampling. Instrumen penelitian berupa kuesioner dan oftalmoskop langsung. Hasil penelitian mendapatkan 18,6\% nelayan mengalami katarak. Kejadian katarak secara bermakna ditemukan pada responden yang berusia $\geq 50$ tahun, pendidikan rendah, dan nelayan yang tidak menggunakan alat pelindung diri. Perlu dilakukan penyuluhan tentang pentingnya penggunaan alat pelindung diri untuk mencegah terjadinya katarak serta perlu dikembangkan upaya kesehatan kerja yang meliputi pemeriksaan kesehatan sebelum kerja, berkala dan khusus dan pengobatan penyakit akibat kerja pada nelayan.
\end{abstract}

Kata kunci: Bali, katarak, nelayan, paparan sinar matahari

\begin{abstract}
Cataract is the most prevalent cause of blindness in the world. Based on occupation, cataract was higher among farmer, fisherman, and labor workers. This study aims to measure the prevalence of cataract among fishermen of the "Putra Samudra" fisherman group at Lebih village. This was a cross-sectional study with quantitative descriptive approach. Samples were 70 fishermen of the 187 members of "Putra Samudra" fishermen group. Sampling technique was simple random sampling. Instrument for the study was questionnaire and direct ophthalmoscope. The result showed that $18.6 \%$ of the fishermen have cataract. Cataract prevalence was significantly higher among the fishermen $\geq 50$ year old, lower education and those who did not wear specific protection aids. It is necessary to provide education on the importance of specific protection aids to prevent cataract. It is also necessary to develop occupational health program that include medical check-up prior working time, regular and specific, also health care for occupational health problems among fishermen.
\end{abstract}

Keywords : Bali, cataract, fishermen, exposure to sun ray

\section{PENDAHULUAN}

Salah satu masalah dalam bidang kesehatan kerja adalah gangguan kesehatan indera penglihatan akibat lingkungan kerja. Mata penting bagi pekerja karena melalui mata pekerja dapat menyerap informasi visual yang digunakan untuk melaksanakan proses pekerjaannya.

Gangguan penglihatan terbanyak disebabkan oleh gangguan refraksi serta katarak. Sedangkan katarak merupakan penyebab kebutaan terbanyak (51\%) di seluruh dunia (Kementerian Kesehatan RI, 2014). Prevalensi katarak menurut Riskesdas 2013 adalah sebesar 1,8\% dari jumlah penduduk Indonesia, yang tertinggi di Provinsi Sulawesi Utara sebesar 3,7\%, sementara Bali $(2,7 \%)$ berada di urutan ke-3 dengan prevalensi katarak terbanyak di Indonesia (Kementerian Kesehatan Republik Indonesia, 2013). Dilihat dari pekerjaan, kelompok pekerjaan petani, nelayan, dan buruh merupakan kelompok pekerjaan 
dengan prevalensi katarak paling tinggi (Kementerian Kesehatan RI, 2014).

Katarak akibat kerja merupakan kekeruhan yang ada pada lensa mata yang menyebabkan menurunnya ketajaman penglihatan akibat faktor risiko di tempat kerja. Gejala yang ditimbulkan yaitu silau, ketajaman penglihatan menurun, penglihatan berkabut, pada pekerja umumnya terjadi pada usia muda (Kementerian Kesehatan Republik Indonesia, 2011). Faktor risiko katarak yaitu umur, jenis kelamin, pendapatan, pendidikan, penyakit diabetes mellitus (DM), paparan asap, paparan sinar matahari (sinar ultraviolet), merokok, riwayat penyakit katarak, dan pekerjaan (Ulandari, 2014).

Nelayan adalah salah satu pekerjaan yang berisiko mengalami katarak. Pencegahan katarak dapat dilakukan pada nelayan yaitu dengan melakukan pencegahan umum dengan mengurangi pajanan terhadap faktor risiko katarak seperti sinar matahari langsung, tidak merokok dan menghindari paparan asap serta memperhatikan upaya pencegahan khusus yaitu dengan memberikan pelindungan mata dan wajah dengan cara memakai topi yang mempunyai pinggiran lebar dan kacamata (Tana, 2006).

Sesuai dengan latar belakang tersebut, penulis tertarik untuk meneliti risiko katarak yang dihadapi nelayan. Tujuan penelitian ini adalah untuk mengetahui kejadian katarak pada kelompok nelayan "Putra Samudra" di Desa Lebih Tahun 2016.

\section{METODE PENELITIAN}

Rancangan penelitian ini adalah deskriptif kuantitatif dengan pendekatan cross-sectional. Sampel dalam penelitian ini berjumlah 70 orang dari populasi sebanyak 187 orang nelayan serta memenuhi kriteria inklusi yaitu nelayan telah bekerja lebih dari setahun serta masih aktif mencari ikan. Sedangkan kriteria eksklusi yaitu nelayan yang tidak bersedia untuk diteliti serta yang sudah menjalani operasi katarak. Teknik pengambilan sampel yang dilakukan adalah simple random sampling. Instrumen yang digunakan adalah kuesioner untuk mengetahui lama paparan sinar matahari, karakteristik nelayan, gaya hidup nelayan, serta perilaku penggunaan alat pelindung diri dan oftalmoskop langsung digunakan untuk memeriksa mata nelayan. Pengumpulan data dilakukan di rumah ketua kelompok nelayan "Putra Samudra" pada bulan April 2016.

Analisis data dilakukan secara univariat dan bivariat. Analisis univariat untuk menggambarkan distribusi frekuensi variabel yang diteliti, sedangkan analisis bivariat dengan tabulasi silang untuk mengetahui distribusi frekuensi kejadian katarak berdasarkan umur, masa kerja, pendidikan, pendapatan, pola penangkapan ikan, lama paparan, merokok, konsumsi alkohol, dan penggunaan alat pelindung diri. Analisis bivariat dilakukan dengan uji chisquare.

\section{HASIL}

Semua sampel bersedia diteliti dan memenuhi syarat penelitian. Karakteristik responden disajikan dalam Tabel 1. 
Tabel 1. Karakteristik Nelayan

\begin{tabular}{lll}
\hline Karakteristik nelayan & F & \% \\
\hline Umur & \multicolumn{1}{l}{} \\
$\leq 34$ tahun & 84 & 11,4 \\
35-44 tahun & 16 & 34,3 \\
$45-54$ tahun & 22 & 22,9 \\
$\geq 55$ tahun & & 31,4 \\
\hline Masa Kerja & 1 & 1,4 \\
$<6$ tahun & 19 & 27,2 \\
6-10 tahun & 50 & 71,4 \\
$>10$ tahun & & \\
\hline Pendidikan & 15 & 21,4 \\
Tidak sekolah & 15 & 21,4 \\
SD & 3 & 4,3 \\
SMP & 37 & 52,9 \\
SMA & & \\
\hline Penghasilan & 31 & 44,3 \\
$<$ Rp 1.904.141 & 39 & 55,7 \\
$\geq$ Rp 1.904.141 & 39 & \\
\hline Pola penangkapan & & 54,3 \\
Satu hari & 38 & \\
Tengah hari & 32 & \\
& & \\
\hline
\end{tabular}

Responden paling banyak (34,3\%) pada kelompok umur 35-44 tahun, disusul kelompok umur $>55$ tahun $(31,4 \%)$. Sebagian besar $(71,4 \%)$ nelayan memiliki masa kerja $>10$ tahun. Tingkat pendidikan responden paling banyak (52,9\%) SMA. Mengacu pada Upah Minimum Regional (UMR) yang berlaku di Kabupaten Gianyar tahun 2016, maka responden kebanyakan (55,7\%) berpenghasilan tinggi. Pola penangkapan ikan yang lebih banyak dilakukan oleh nelayan "Putra Samudra" yaitu pola penangkapan satu hari (54,3\%), dan tidak ada responden dengan pola penangkapan ikan lebih dari satu hari.

Tabel 2. Gaya Hidup Nelayan

\begin{tabular}{lll}
\hline Gaya hidup nelayan & F & \% \\
\hline Kebiasaan merokok & & \\
Merokok & 54 & 77,1 \\
$\quad-\quad 10$ batang/hari & 16 & 29,6 \\
$-\quad 10-20$ batang/hari & 21 & 38,9 \\
\hline
\end{tabular}




\begin{tabular}{lll}
\hline$\quad$ - $\geq 20$ batang/hari & 17 & 31,5 \\
Tidak merokok & 16 & 22,9 \\
\hline Konsumsi alkohol & & \\
Mengonsumsi alkohol & 35 & 50,0 \\
$\quad-\quad$ Tidak sering mengonsumsi & 21 & 60,0 \\
$\quad-\quad$ Sering mengonsumsi & & 40,0 \\
Tidak mengonsumi & 14 & \\
& & 50,0 \\
\hline
\end{tabular}

Gaya hidup responden dilihat dari kebiasaan merokok dan konsumsi alkohol. Sebagian besar (77,1\%) responden merupakan seorang perokok aktif dan kebanyakan (38,9\%) merupakan merokok sebanyak 10-20 batang/hari. Untuk perilaku konsumsi alkohol, setengah dari responden mengonsumsi alkohol namun kebanyakan $(60 \%)$ responden memiliki kebiasaan jarang mengonsumsi alkohol.

Tabel 3. Paparan Sinar Matahari

\begin{tabular}{lll}
\hline Paparan Sinar Matahari & F & \% \\
\hline Tidak berisiko & 46 & 65,7 \\
Berisiko & 24 & 34,3 \\
\hline
\end{tabular}

Lama paparan sinar matahari adalah rata-rata lama paparan sinar matahari yang dialami oleh nelayan selama mencari ikan.
Dari 70 orang responden, didapatkan 65,7\% terpapar sinar matahari kurang dari 4 jam/hari.

Tabel 4. Penggunaan APD

\begin{tabular}{lll}
\hline Penggunaan APD & F & \% \\
\hline Menggunakan APD lengkap & 24 & 34,3 \\
Menggunakan salah satu APD & 26 & 37,1 \\
Tidak menggunakan APD & 20 & 28,6 \\
\hline
\end{tabular}

Hanya sepertiga responden yang mempergunakan alat pelindung diri lengkap berupa topi dan kaca mata, bahkan ada yang tidak mempergunakan APD sama sekali/pemakaian APD yang tidak lengkap.
Kebanyakan responden mempergunakan salah satu APD berupa topi. Dari 70 orang responden yang menjalani pemeriksaan mata, sebanyak $18,6 \%$ yang mengalami katarak. 
Tabel 5. Kejadian Katarak Berdasarkan Karakteristik, Lama Paparan Ultra Violet, Gaya Hidup Nelayan, dan Penggunaan Alat Pelingdung Diri

\begin{tabular}{|c|c|c|c|c|}
\hline \multirow{3}{*}{$\begin{array}{c}\text { Karakteristik, Lama } \\
\text { Paparan Sinar Matahari, } \\
\text { Gaya Hidup Nelayan, } \\
\text { Penggunaan APD }\end{array}$} & \multicolumn{2}{|c|}{ Katarak } & \multirow[t]{2}{*}{ Total } & \multirow[t]{3}{*}{ p-value } \\
\hline & Ya & Tidak & & \\
\hline & $\begin{array}{c}\text { Frekuensi } \\
(\%)\end{array}$ & $\begin{array}{c}\text { Frekuensi } \\
(\%)\end{array}$ & $\begin{array}{c}\text { Frekuensi } \\
\quad(\%)\end{array}$ & \\
\hline \multicolumn{5}{|l|}{ Umur } \\
\hline$<50$ tahun & $2(4,7)$ & $41(95,3)$ & $43(100)$ & $p=0,000$ \\
\hline$\geq 50$ tahun & $11(40,7)$ & $16(59,3)$ & $27(100)$ & \\
\hline \multicolumn{5}{|l|}{ Masa Kerja } \\
\hline Baru & $2(10,0)$ & $18(90,0)$ & $20(100)$ & $\mathrm{p}=0,243$ \\
\hline Lama & $11(22,0)$ & $39(78,0)$ & $50(100)$ & \\
\hline \multicolumn{5}{|l|}{ Pendidikan } \\
\hline Pendidikan rendah & $11(33,3)$ & $22(66,7)$ & $33(100)$ & $p=0,003$ \\
\hline Pendidikan tinggi & $2(5,4)$ & $35(94,6)$ & $57(100)$ & \\
\hline \multicolumn{5}{|l|}{ Penghasilan } \\
\hline Penghasilan rendah & $8(25,8)$ & $23(74,2)$ & $31(100)$ & $\mathrm{p}=0,165$ \\
\hline Penghasilan tinggi & $5(12,8)$ & $34(87,2)$ & $39(100)$ & \\
\hline \multicolumn{5}{|l|}{ Pola Penangkapan } \\
\hline Satu hari & $7(18,4)$ & $31(81,6)$ & $38(100)$ & $\mathrm{p}=0,972$ \\
\hline Tengah hari & $6(18,7)$ & $26(81,2)$ & $32(100)$ & \\
\hline \multicolumn{5}{|l|}{ Lama Paparan } \\
\hline Berisiko & $5(20,8)$ & $19(79,2)$ & $24(100)$ & $\mathrm{p}=0,725$ \\
\hline Tidak berisiko & $8(17,4)$ & $38(82,6)$ & $46(100)$ & \\
\hline \multicolumn{5}{|l|}{ Merokok } \\
\hline Tidak merokok & $3(18,7)$ & $13(81,3)$ & $16(100)$ & $p=0,983$ \\
\hline Merokok & $10(18,5)$ & $44(81,5)$ & $54(100)$ & \\
\hline \multicolumn{5}{|l|}{ Konsumsi alkohol } \\
\hline Tidak mengonsumsi & $7(20,0)$ & $28(80,0)$ & $35(100)$ & $\mathrm{p}=0,759$ \\
\hline Mengonsumsi & $6(17,1)$ & $29(82,9)$ & $35(100)$ & \\
\hline \multicolumn{5}{|l|}{ Penggunaan APD } \\
\hline Menggunakan & $5(10.0)$ & $45(90.0)$ & $50(100)$ & $p=0,004$ \\
\hline Tidak menggunakan & $8(40,0)$ & $12(60,0)$ & $20(100)$ & \\
\hline Total & $13(18,6)$ & $57(81,4)$ & $70(100)$ & \\
\hline
\end{tabular}


Tabel 5 menunjukkan bahwa proporsi kejadian katarak lebih tinggi secara bermakna pada kelompok umur $\geq 50$ tahun $(p=0,000)$, pendidikan rendah $(p=0,003)$, dan pada responden yang tidak menggunakan alat pelindung diri $(p=0,004)$. Sedangkan

\section{DISKUSI}

Kejadian katarak pada nelayan "Putra Samudra" sebanyak 18,6\%. Dengan menggunakan metode cross-sectional study yang sama dengan Tana, dkk., (2007) mendapatkan hasil kasus katarak yang diperoleh dari pemeriksaan dokter mata mencapai $37,9 \%$. Selain petani, nelayan juga merupakan salah satu pekerjaan yang berisiko mengalami katarak (Kementerian Kesehatan Republik Indonesia, 2013). Rendahnya kejadian katarak pada kelompok nelayan "Putra Samudra" disebabkan karena sebagian besar paparan sinar matahari yang dialami nelayan "Putra Samudra" kurang dari 4jam/hari atau tidak berisiko. Selain itu, pada kelompok nelayan "Putra Samudra" pernah terdapat pelayanan upaya kesehatan kerja (UKK) yaitu pembagian alat pelindung diri gratis berupa seragam kerja yang terdiri dari baju lengan panjang, mantel, topi, serta kacamata hitam dari Dinas Ketenagakerjaan dan Transmigrasi pada tahun 2014.

Meskipun alat pelindung diri telah dibagikan secara gratis, namun masih ada nelayan yang tidak mau menggunakan alat pelindung diri saat bekerja. Hal tersebut terjadi karena kurangnya penyuluhan kesehatan kerja tentang risiko pekerjaan, pencegahan kecelakaan kerja, penggunaan variabel yang lain seperti masa kerja $(\mathrm{p}=0,243)$, penghasilan $(\mathrm{p}=0,165)$, pola penangkapan ikan $(\mathrm{p}=0,972)$, lama paparan sinar matahari $(\mathrm{p}=0,725)$, merokok $(\mathrm{p}=0,983)$, dan konsumsi alkohol $(p=0,759)$ tidak menunjukkan perbedaan yang bermakna dengan kejadian katarak

alat pelindung diri, dan kesehatan lingkungan kerja pada nelayan. Sehingga masih ada kejadian katarak pada kelompok nelayan "Putra Samudra".

Umur merupakan faktor risiko utama dari katarak. Menurut WHO, gangguan penglihatan dan kebutaan banyak terjadi pada kelompok umur 50 tahun dan lebih. Umur $\geq 50$ tahun memiliki hubungan yang bermakna terhadap kejadian katarak. Hal tersebut sejalan dengan penelitian yang dilakukan oleh Tana, dkk., (2007) dan Rasyid, dkk., (2010). Tana, dkk., (2007) menyebutkan seseorang yang berumur 55 tahun ke atas mempunyai kejadian katarak lebih tinggi dibandingkan yang berumur 30-54 tahun. Selain itu, penelitian yang dilakukan Rasyid, dkk., (2010) juga menyebutkan penderita katarak $72,7 \%$ berusia $\geq 40$ tahun, sedangkan sisanya berusia $<40$ tahun. Dengan bertambahnya umur seseorang akan menyebabkan bertambahnya risiko katarak (Ulandari, 2014).

Prevalensi katarak juga lebih tinggi pada orang yang berpendidikan rendah. Dilihat dari tingkat pendidikan nelayan, mendapatkan tingkat pendidikan memiliki hubungan yang bermakna dengan kejadian katarak. Dengan mengelompokkan tingkat pendidikan dengan cara yang sama dengan 
penelitian yang dilakukan oleh Ulandari (2014), mendapatkan hasil prevalensi katarak lebih tinggi pada kelompok yang berpendidikan rendah. Sejalan dengan hasil dari penelitian Hutasoit (2009) yang menemukan pendidikan terakhir penderita katarak yaitu sekolah dasar. Arimbi (2012) juga menemukan seseorang yang berpendidikan rendah berisiko lebih tinggi menderita katarak dibandingkan pendidikan tinggi. Tingkat pendidikan pada nelayan akan berdampak pada adanya pemahaman dan kesadaran diri untuk mencari informasi terkait katarak (Ulandari, 2014).

Penggunaan alat pelindung diri seperti topi serta kacamata hitam merupakan salah satu pencegahan yang dapat dilakukan agar tidak terkena katarak. Penggunaan alat pelindung diri dengan kejadian katarak memiliki hubungan yang bermakna dengan kejadian katarak. Hal tersebut sesuai dengan pendapat Tana (2006) yang mengungkapkan untuk mecegah terjadinya katarak pada pekerja dapat dilakukan dengan pencegahan secara umum dengan mengurangi pajanan terhadap faktor risiko katarak seperti sinar matahari langsung, tidak merokok dan menghindari paparan asap serta memperhatikan upaya pencegahan khusus yaitu dengan memberikan pelindungan mata dan wajah dengan cara memakai topi yang mempunyai pinggiran lebar dan kacamata. Nelayan yang terpapar sinar matahari lebih dari 4 jam/hari perlu membatasi pajanan sinar matahari tersebut. Pembatasan paparan sinar matahari dilakukan dengan menganjurkan pekerja luar ruangan untuk memberikan perlindungan pada matanya dengan memakai topi yang mempunyai pinggiran lebar dan kacamata. Paparan terhadap cahaya matahari pada pukul 10.0014.00 perlu dihindari.

Perilaku penggunaan alat pelindung diri pada nelayan "Putra Samudra" berbagai macam, ada nelayan yang menggunakan alat pelindung diri lengkap berupa topi dan kacamata hitam, ada yang menggunakan salah satunya yaitu topi, dan ada yang sama sekali tidak menggunakan. Penggunaan alat pelindung diri juga memiliki kelemahan untuk mencegah terjadinya katarak. Kelemahan dari alat pelindung diri menurut Tarwaka (2008) antara lain alat pelindung diri tidak menghilangkan risiko yang ada, tetapi hanya membatasi pajanan yang diterima dan penggunaan alat pelindung diri dirasakan tidak nyaman pada pekerja.

\section{SIMPULAN}

Kejadian katarak pada nelayan "Putra Samudra" sebanyak 18,6\% dan sebagian besar mengalami katarak pada kedua matanya. Kejadian katarak pada kelompok nelayan "Putra Samudra" secara bermakna lebih tinggi pada umur $\geq 50$ tahun, pendidikan rendah serta nelayan yang tidak menggunakan alat pelindung diri.

\section{SARAN}

Bagi nelayan "Putra Samudra" sebaiknya lebih memperhatikan keselamatan dan kesehatan kerja seperti dengan selalu menggunakan alat pelindung diri selama mencari ikan untuk mencegah terjadinya penyakit akibat kerja seperti katarak pada nelayan. Perlu dilakukannya penyuluhan terkait pentingnya penggunaan alat pelindung diri pada nelayan "Putra Samudra" untuk mencegah terjadinya katarak pada nelayan mengingat nelayan 
merupakan salah satu pekerjaan yang berisiko mengalami katarak serta dalam proses pekerjaannya selalu terpapar sinar matahari. Upaya kesehatan kerja lain pada nelayan yang bisa dikembangkan yaitu; pemeriksaan kesehatan sebelum kerja, berkala dan khusus, pemantauan kesehatan lingkungan, dan pengobatan penyakit akibat kerja pada nelayan.

\section{DAFTAR PUSTAKA}

Arimbi, A. T. (2012). Faktor-faktor yang Berhubungan dengan Katarak Degeneratif di RSUD Budhi Asih Tahun 2011. Skripsi. Universitas Indonesia

Hutasoit, H. (2009). Prevalensi Kebutaan Akibat Katarak di Kabupaten Tapanuli Selatan. Tesis. Universitas Sumatera Utara

Kementerian Kesehatan Republik Indonesia. (2011). Pedoman Tatalaksana Penyakit Akibat Kerja Bagi Petugas Kesehatan: Penyakit Mata Akibat Kerja. Kementrian Kesehatan Republik Indonesia. Jakarta

Kementerian Kesehatan Republik Indonesia. (2013). Riset Kesehatan Dasar. Jakarta: Badan Penelitian dan Pengembangan Kesehatan. Jakarta

Kementerian Kesehatan Republik Indonesia. (2014). Situasi Gangguan Penglihatan dan Kebutaan. Pusat Data dan Informasi Kementrian Kesehatan RI. Jakarta

Rasyid, R., Nawi, R., dan Zulkifli A. H. A. (2010). Faktor yang Berhubungan dengan Kejadian Katarak di Balai Kesehatan Mata Masyarakat Makassar (BKMM) Tahun 2010. Universitas Hasanuddin.

Tana, L. (2006). Faktor Risiko dan Upaya Pencegahan Katarak pada Kelompok Pekerja. Badan Litbangkes Depkes RI. Jakarta.

Tana, L., Mihardja, L., dan Rif'ati, L. (2007). Merokok dan Usia sebagai Faktor Risiko Katarak pada Pekerja Berusia $\geq 30$ Tahun di Bidang Pertanian. Jurnal Universa Medicina. $120-8$

Tarwaka. (2008). Manajemen dan Implementasi K3 di Tempat Kerja. Surakarta: Harapan Press.

Ulandari, N. N. S. T. (2014). Pengaruh Pekerjaan dan Pendidikan terhadap Terjadinya Katarak Pada Pasien yang Berobat di Balai Kesehatan Mata Masyarakat Nusa Tenggara Barat. Tesis. Universitas Udayana.

World Health Organization. Blindness: Vision 2020 - the global initiative for the elimination of avoidable blindness. 